\title{
Astragalus polysaccharide enhances the immune function of RAW264.7 macrophages via the NF-кB p65/MAPK signaling pathway
}

\author{
SHIBIN FENG ${ }^{*}$, HONGYAN DING* ${ }^{*}$ LEIHONG LIU, CHENGLU PENG, YINGYING HUANG, \\ FUCHAO ZHONG, WEI LI, TINGTING MENG, JINCHUN LI, XICHUN WANG, YU LI and JINJIE WU \\ College of Animal Science and Technology, Anhui Agricultural University, Hefei, Anhui 230036, P.R. China
}

Received January 19, 2020; Accepted September 30, 2020

DOI: $10.3892 /$ etm.2020.9452

\begin{abstract}
The aim of the present study was to investigate the immunoregulatory effects of Astragalus polysaccharide (APS) on RAW264.7 cells. The production of cytokines by RAW264.7 cells was analyzed using ELISA, while cell viability and optimal concentration of APS were assessed using the Cell Counting Kit- 8 assay. In addition, the mRNA levels of IL-6, inducible nitric oxide synthase (iNOS) and TNF- $\alpha$ were determined by reverse transcription-quantitative PCR analysis. The levels of co-stimulatory molecules and cell cycle distribution were assessed by flow cytometry. Electrophoretic mobility shift assay was used to determine the effects of APS on p65 expression. Compared with controls, APS enhanced the production of NO, the gene expression of TNF- $\alpha$, IL- 6 and iNOS and the protein levels of phosphorylated p65, p38, Jun $\mathrm{N}$-terminal kinase and extracellular signal regulated kinase in RAW264.7 cells, whereas these effects of APS were alleviated by pyrrolidine dithiocarbamate. The results of the present study indicated that the immunoregulatory effects of APS are mediated, at least in part, via the activation of the $\mathrm{NF}-\kappa \mathrm{B}$ p65/MAPK signaling pathway.
\end{abstract}

\section{Introduction}

Radix Astragali, popularly known as Huangqi in Chinese or Milkvetch in English, mainly contains astragaloside IV, Astragalus polysaccharide (APS) and Astragalus flavonoids (1). Scientific investigations have revealed that APS has

Correspondence to: $\mathrm{Dr} \mathrm{Yu} \mathrm{Li}$ or Professor Jinjie $\mathrm{Wu}$, College of Animal Science and Technology, Anhui Agricultural University, 130 Changjianxilu, Hefei, Anhui 230036, P.R. China

E-mail: lydhy2014@ahau.edu.cn

E-mail: wjj@ahau.edu.cn

${ }^{*}$ Contributed equally

Key words: Astralagus polysaccharide, nuclear factor- $\kappa \mathrm{B}$ signaling pathway, RAW264.7 cells, immune function various biological activities, such as immunomodulatory, antioxidant, antitumor, anti-inflammatory, anti-atherosclerotic, hematopoietic and neuroprotective properties (2,3). Previous studies have also shown that APS significantly increased the phagocytotic activity of macrophages and promoted lymphocyte proliferation $(4,5)$. RAW264.7 mouse macrophages, popularly used in the study of immune mechanisms, occupy a unique niche in the immune system. They can kill pathogens directly by phagocytosis and indirectly via the secretion of pro-inflammatory factors (6). RAW264.7 mouse macrophages are responsible for functions such as antigen processing and presentation to antigen-specific $\mathrm{T}$ cells (7). Following activation, RAW264.7 cells can induce the expression of accessory and co-stimulatory molecules that promote sustained stimulatory interactions with $\mathrm{T}$ cells and the generation of adaptive immunity (8-10).

CD40, CD80 and CD86 are known as co-stimulatory molecules that are required for $\mathrm{T}$ cell activation (11). It was demonstrated that the differential expression of co-stimulatory molecules on antigen-presenting cells plays an essential role in directing the $\mathrm{T}$-cell response to proinflammatory or regulatory effector functions (12). CD40 interacts with CD40L, which is known to play key roles in the in vitro and in vivo activation and differentiation of B cells (13). In vivo results indicated that aberrant expression of co-stimulatory molecules is sufficient for the initiation of an autoimmune response (14). Therefore, CD40, CD80 and CD86 are responsible for functions such as antigen processing and presentation to antigen-specific $\mathrm{T}$ cells. Thus, the increase in the expression of the surface molecules CD40, CD80 and CD86 indicates enhanced immune response. It was previously demonstrated that RAW264.7 cells play an important role as an interface between innate and adaptive immunity (15). Therefore, it was deemed necessary to investigate the effects of APS on CD40, CD80 and CD86 expression in RAW264.7 cells.

$\mathrm{NF}-\kappa \mathrm{B}$ is a ubiquitous transcription factor of inflammatory genes. The MAPK signaling pathway is an important regulator of numerous extracellular stimuli (16). In recent years, it was reported that the activation of the NF- $\kappa$ B/MAPK signaling pathway plays a key role in resistance to pathogens or mechanical injury (17). A number of experimental and clinical studies have investigated the effects of APS in the 
clinical setting. APS regulates humoral and cellular immunity via the Toll-like receptor 4 signaling pathway, affecting the function of $\mathrm{T}$ cells and thus may be used as an adjuvant for vaccines (18). The activation of $\mathrm{NF}-\kappa \mathrm{B} / \mathrm{Rel}$ may be involved in the ability of APS to induce cytokine production by macrophages and RAW264.7 macrophages, leading to the enhancement of immune function $(19,20)$. However, the exact molecular mechanism through which this induction affects immune function remains to be elucidated. The aim of the present study was to study the effects of APS on the activation of the NF- $\kappa$ B/MAPK signaling pathway.

\section{Materials and methods}

Reagents. APS (purity >98\%; cat. no. B20562-20mg) was purchased from Shanghai Yuanye Bio-Technology Co., Ltd. DMEM with high glucose was obtained from HyClone (Cytiva). FBS was purchased from Clark Bioscience. Cell Counting Kit-8 (CCK-8) was purchased from Dojindo Molecular Technologies, Inc. Cell cycle and mouse TNF- $\alpha$ (cat.no.KGEMC102a), mouse IL-6 (cat.no. KGEMC004-1) and mouse IL-1 $\beta$ (cat. no. KGEMC001b) ELISA kits were obtained from Nanjing KeyGen Biotech Co., Ltd. Nitric oxide (NO) assay kit (cat. no. S0021) was obtained from Beyotime Institute of Biotechnology. Biozol RNA extraction reagent, Biomiga First-Strand cDNA Synthesis kit and quantitative PCR (qPCR) kit were obtained from Biomiga, Inc. The primary antibodies used in this study included anti- $\beta$-actin (cat.no. AF0003; $1: 500$ ), anti-p38 (cat. no. AM065; 1:500), anti-phosphorylated (p)-p38 (cat. no. AM063; 1:500), anti-p65 (cat. no. AF0246; 1:500), anti-p-p65 (cat. no. AN371; 1:500), anti-ERK (cat. no. AM076; 1:500), anti-p-ERK (cat. no. AP328; 1:500), anti-JNK (cat. no. AJ516; 1:500) and anti-p-JNK (cat. no. AJ518; 1:500), and HRP-conjugated anti-mouse and anti-rabbit secondary antibodies (cat. nos. A0216 and A0208; 1:500) were purchased from Beyotime Institute of Biotechnology. The pacific blue anti-mouse CD40 (cat. no. 124626; 1:500), phycoerythrin anti-mouse CD80 (cat. no. 104708; 1:400) and FITC anti-mouse CD86 (cat. no. 105006; 1:500) antibodies and the corresponding isotype controls (cat. no. 405404; 1:1000) were purchased from BioLegend, Inc.

Cell culture and treatment. RAW264.7 macrophages were obtained from Jilin University (Jilin, China) and cultured in DMEM with high glucose containing $10 \%$ FBS and $1 \%$ antibiotics $(100 \mathrm{U} / \mathrm{ml}$ penicillin and $100 \mu \mathrm{g} / \mathrm{ml}$ streptomycin) as previously described $(19,20)$. The cells were cultured at $37^{\circ} \mathrm{C}$ and $5 \% \mathrm{CO}_{2}$ and the culture medium was replaced every $48 \mathrm{~h}$. The cells were pretreated with or without $5 \mu \mathrm{mol} / 1$ pyrrolidine dithiocarbamate (PDTC; NF- $\mathrm{B}$ inhibitor; cat. no. S1809; Beyotime Biotechnology, China) $1 \mathrm{~h}$ before treatment with $0,25,50$ or $100 \mu \mathrm{g} / \mathrm{ml}$ APS.

Evaluating the optimal concentration of APS and RAW264.7 cell viability by $C C K-8$ assay. Cells were adjusted to a volume of $1 \times 10^{5}$ cells $/ \mathrm{ml}$ and $100 \mu \mathrm{l}$ of the cultured cells were selected, plated in a 96-well plate and incubated at $37^{\circ} \mathrm{C}$ and $5 \% \mathrm{CO}_{2}$ for $24 \mathrm{~h}$. Subsequently, $10 \mu \mathrm{l}$ CCK- 8 solution was added to each well and the cells were incubated for an additional $4 \mathrm{~h}$. The optical density was measured at a wavelength of
$450 \mathrm{~nm}$ using a plate reader (Multiskan MK3; Thermo Fisher Scientific, Inc.).

Evaluation of IL-6,TNF- $\alpha, I L-\beta$ and NO secretion by ELISA and mRNA expression levels by reverse transcription (RT)-qPCR analysis. RAW264.7 cells $\left(1 \times 10^{5}\right.$ cells $\left./ \mathrm{ml}\right)$ were seeded in 6-well plates, incubated overnight and then exposed to $\operatorname{APS}(0,25,50$ and $100 \mu \mathrm{g} / \mathrm{ml})$ and PDTC (5 $\mu \mathrm{mol} / 1)$ for $24 \mathrm{~h}$ as previously described $(19,20)$. Cell supernatants were collected by centrifugation at $3,500 \times \mathrm{g}\left(4^{\circ} \mathrm{C}\right)$ for $10 \mathrm{~min}$. The amount of IL- 6 , TNF- $\alpha$, IL- $1 \beta$ and NO secretion in the culture supernatants were determined in duplicate using respective ELISA kits according to the manufacturer's instructions.

Total RNA was isolated from RAW264.7 cells using TRIzol ${ }^{\circledR}$ reagent and the RNA was reverse transcribed into cDNA $\left(1 \mathrm{~h}\right.$ at $\left.37^{\circ} \mathrm{C}\right)$ with a First Strand cDNA Synthesis kit. The relative mRNA expression levels were detected using a Biomiga SYBR qPCR mix kit on an ABI 7500 Real-Time PCR system (Applied Biosystems, Thermo Fisher Scientific, Inc.). The following thermocycling conditions were used for the qPCR: Initial denaturation for $5 \mathrm{~min}$ at $94^{\circ} \mathrm{C}$; followed by 30 cycles of $30 \mathrm{sec}$ at $94^{\circ} \mathrm{C}, 40 \mathrm{sec}$ at $55^{\circ} \mathrm{C}$ and $2 \mathrm{~min}$ at $72^{\circ} \mathrm{C}$; and a final extension for $7 \mathrm{~min}$ at $72^{\circ} \mathrm{C}$. Analysis of relative gene expression data was performed using the $2^{-\Delta \Delta \mathrm{Cq}}$ method (21). The primer sequences of IL-1 $\beta$, IL-6, TNF- $\alpha$, inducible nitric oxide synthase (iNOS) and GAPDH that were used for RT-qPCR are designed by Primer 5.0 software according to the sequences in Genebank and are presented in Table I.

Evaluation of CD40, CD80 and CD86 expression. Cells were collected following treatment with PDTC and different concentrations $(0-100 \mu \mathrm{g} / \mathrm{ml})$ of APS for $24 \mathrm{~h}$. The cell surfaces were blocked with $5 \%$ goat serum (cat. no. C0256; Beyotime Institute of Biotechnology) at $4^{\circ} \mathrm{C}$ for $15 \mathrm{~min}$ and washed twice with PBS ( $\mathrm{pH}$ 7.2). Subsequently, the cells were incubated with monoclonal antibodies against CD40, CD80, CD86 and the corresponding fluorescent markers for $30 \mathrm{~min}$ at $4^{\circ} \mathrm{C}$. After the cells were washed twice with PBS and resuspended in PBS, they were subjected to flow cytometry on a FACS platform and CellQuest software Version 3.0 (Becton, Dickinson \& Company).

Flow cytometry analysis of cell cycle regulation. RAW264.7 cells $\left(1 \times 10^{6}\right.$ cells $\left./ \mathrm{ml}\right)$ were seeded in 6-well plates and treated with various concentrations $(0-100 \mu \mathrm{g} / \mathrm{ml})$ of APS in the presence or absence of PDTC for $24 \mathrm{~h}$. Subsequently, the cells were collected, washed once with cold PBS, fixed in $75 \%$ cold ethanol overnight at $4^{\circ} \mathrm{C}$ and washed twice with cold PBS. The fixed cells were resuspended in $100 \mu \mathrm{l}$ RNase (cat. no. ST577; Beyotime Institute of Biotechnology) at $37^{\circ} \mathrm{C}$ and incubated with $400 \mu \mathrm{l} \mathrm{PI}$ at $4^{\circ} \mathrm{C}$ in a dark room for $30 \mathrm{~min}$. Cell cycle progression was analyzed using flow cytometry on a FACS platform and Cell Quest software Version 3.0 (Becton, Dickinson \& Company).

Evaluation of p65 expression by electrophoretic mobility shift assay (EMSA). Briefly, nuclear protein from RAW264.7 cells was extracted with a nuclear protein extraction kit (cat. no. C500009; Sangon Biotech Co., Ltd.) according to 
Table I. Primer sequences used in reverse transcription-quantitative PCR analysis.

\begin{tabular}{lccl}
\hline Gene name & Product size $(\mathrm{bp})$ & Gene ID & \multicolumn{1}{c}{ Primer sequence (5'-3') } \\
\hline IL-1 $\beta$ & 165 & 16176 & $\begin{array}{l}\text { Forward: GCCACCTTTTGACAGTGATGAG } \\
\text { Reverse: AGTGATACTGCCTGCCTGAAG } \\
\text { IL-6 }\end{array}$ \\
& 201 & 16193 & $\begin{array}{l}\text { Forward: CAACGATGATGCACTTGCAGA } \\
\text { Reverse: TCTCTCTGAAGGACTCTGGCT }\end{array}$ \\
TNF- $\alpha$ & 161 & 21926 & Forward: ACCTGGCCTCTCTACCTTGT \\
iNOS & 156 & Reverse: CCCGTAGGGCGATTACAGTC \\
GAPDH & & Forward: AGGGACTGAGCTGTTAGAGACA \\
& 232 & Reverse: AAGAGAAACTTCCAGGGGCAAG \\
& & 14433 & Forward: GGTGAAGGTCGGTGTGAACG \\
\end{tabular}

iNOS, inducible nitric oxide synthase.

the manufacture's instruction. After the cell medium was aspirated, $10 \mathrm{ml}$ pre-cold $1 \mathrm{X}$ PBS was added to remove the culture solution. The cells were scraped with a cell scraper. The cells and culture medium were transferred to a centrifuge tube and centrifuged at $800 \mathrm{xg}$ for $10 \mathrm{~min}$ at $4^{\circ} \mathrm{C}$. The supernatant was discarded and $10 \mathrm{ml}$ pre-cold $1 \mathrm{X}$ PBS was added to wash twice via centrifuging at $800 \mathrm{x} \mathrm{g}(3,000 \mathrm{rpm})$ for $5 \mathrm{~min}$ at $4^{\circ} \mathrm{C}$. $0.3 \mathrm{ml}$ pre-cold hypotonic buffer (include $5 \mu 1$ phosphatase inhibitor, $10 \mu \mathrm{l}$ PMSF and $1 \mu 1$ DTT in $1 \mathrm{~m}$ of pre-cold hypotonic buffer) was added to centrifugate tube and then transferred to new tubes. The tube was flicked with fingers to suspend the precipitate, bathed on ice for $10 \mathrm{~min}$, shaken for $10 \mathrm{sec}$. The suspension was centrifuged at $800 \mathrm{x} \mathrm{g}(3,000 \mathrm{rpm})$ at $4^{\circ} \mathrm{C}$ for $5 \mathrm{~min}$. The supernatant was discarded immediately. $0.4 \mathrm{ml}$ pre-cold hypotonic buffer added to wash the pellet with shaking for $30 \mathrm{sec}$. Then, the tubes were centrifuged at $4^{\circ} \mathrm{C}, 2,500 \times \mathrm{g}(5,000 \mathrm{rpm})$ for 5 min. The supernatant was discarded and the precipitate was saved. $0.2 \mathrm{ml}$ lysis buffer (contain $5 \mu \mathrm{l}$ phosphatase inhibitor, $10 \mu \mathrm{l}$ PMSF and $1 \mu \mathrm{l}$ DTT in $1 \mathrm{ml}$ pre-cold lysis buffer)) was added to the precipitate to suspend the precipitate. Then the suspension was bathed in ice for $20 \mathrm{~min}$ and centrifuged at $20,000 \mathrm{x}$ g for $10 \mathrm{~min}$ at $4^{\circ} \mathrm{C}$. The precipitate was discarded and the supernatant is the nuclear protein extract. The nuclear protein extract was stored at $-80^{\circ} \mathrm{C}$ for EMSA assay. The protein concentration was measured using a Bio-Rad protein assay reagent (Bio-Rad Laboratories, Inc.). p65 probes were labeled with biotin for $30 \mathrm{~min}$ at $37^{\circ} \mathrm{C}$. Equal amounts $(4 \mu \mathrm{g})$ of nuclear protein from each sample were included in the binding reaction for $20 \mathrm{~min}$ at room temperature using a Lightshift EMSA Optimization and Control kit (Pierce; Thermo Fisher Scientific, Inc.) according to the manufacturer's instructions. Protein-DNA complexes were separated using non-denaturing $6.5 \%$ polyacrylamide Tris-borate-EDTA electrophoresis gels and transferred to nylon membranes. Biotin-labelled probes were detected using a chemiluminescence solution (Pierce; Thermo Fisher Scientific, Inc.). Labelled bands were measured using a G-BOX Chemi XR5 gel imager (Syngene Europe).
Evaluation of $N F-\kappa B / M A P K$ signaling pathway by western blotting. RAW264.7 cell proteins were extracted with RIPA lysis buffer (cat. no. C500007; Sangon Biotech Co., Ltd.) containing protease (cat. no. BL104A; BioSharp Life Sciences) and phosphatase inhibitor (cat. no. BL612A; BioSharp Life Sciences). Protein (40 $\mu \mathrm{g} /$ lane) was electrophoresed on a $12 \%$ acrylamide resolving gel and 5\% stacking gel, then transferred to a PVDF membrane (EMD Millipore) for $30 \mathrm{~min}$ at $120 \mathrm{~V}$. The membrane was blocked with $5 \%$ BSA (Biosharp Life Sciences) for $4 \mathrm{~h}$ at $26^{\circ} \mathrm{C}$ and incubated with the appropriate diluted primary antibody at $4^{\circ} \mathrm{C}$ for $16 \mathrm{~h}$. Following five washes with TBS containing $0.05 \%$ Tween-20 (TBS-T), the membrane was incubated with HRP-conjugated anti-mouse or anti-rabbit secondary antibodies (cat. nos. A0216 and A0208; 1:500). The membrane was washed in TBS-T thrice, visualized by chemiluminescence (cat. no. 32109; Thermo Fisher Scientific, Inc.) and the results were analyzed using Quantity One Software version 4.6.9 (Bio-Rad Laboratories, Inc.).

Statistical analysis. All values are expressed as the mean \pm SD with three or five replications in one treatment and analyzed with the SPSS software package 17.0 (SPSS Inc.). The differences among experimental groups were analyzed using one-way ANOVA with post hoc multiple comparison of means using the Duncan's multiple range test. $\mathrm{P}<0.05$ was considered to indicate a statistically significant difference.

\section{Results}

Effects of APS on cell proliferation. As shown in Fig. 1, RAW264.7 cells were treated with different concentrations of APS $(0-200 \mu \mathrm{g} / \mathrm{ml})$. At the concentration range of $0-100 \mu \mathrm{g} / \mathrm{ml}$, the cell viability gradually increased with the increase in APS concentration and reaching the maximum at $100 \mu \mathrm{g} / \mathrm{ml}$. When the concentration of APS was $100-200 \mu \mathrm{g} / \mathrm{ml}$, the cell viability decreased gradually upon increased APS concentration. Therefore, $100 \mu \mathrm{g} / \mathrm{ml}$ APS was determined as the optimum concentration for subsequent experiments. 


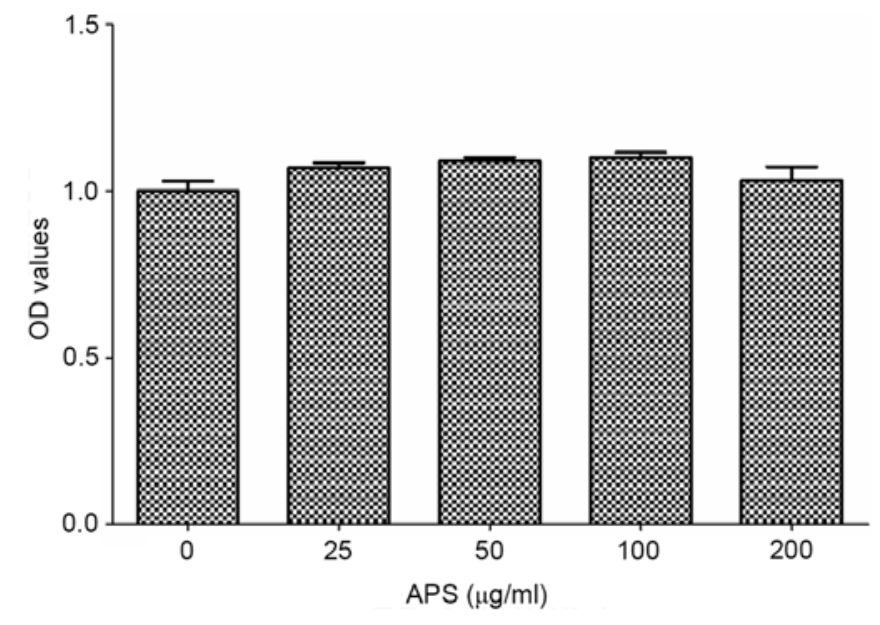

Figure 1. Effects of APS on the cell proliferation rate. Cells were treated with different concentrations of APS $(0-200 \mu \mathrm{g} / \mathrm{ml})$. All values are expressed as the mean \pm standard deviation of at least five replications in each treatment. APS, Astralagus polysaccharide; OD, optical density.

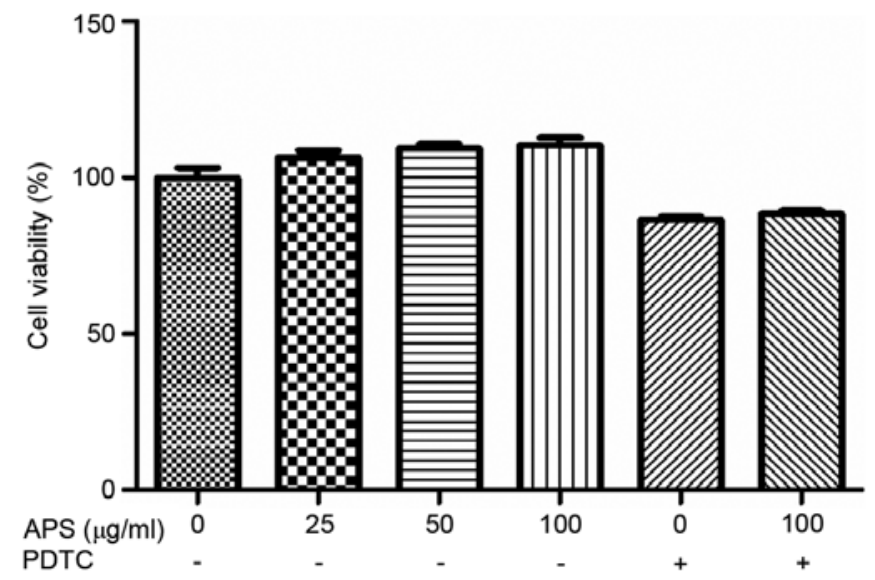

Figure 2. Effects of various concentrations of APS on cell viability. Cells were treated with different concentrations of APS $(0-200 \mu \mathrm{g} / \mathrm{ml})$ with or without PDTC $(5 \mu \mathrm{mol} / \mathrm{ml})$. All values are expressed as the mean \pm standard deviation of at least five replications in each treatment. APS, Astralagus polysaccharide; PDTC, pyrrolidine dithiocarbamate.

As shown in Fig. 2, compared with $0 \mu \mathrm{g} / \mathrm{ml}$ APS treatment group, $25-100 \mu \mathrm{g} / \mathrm{ml}$ APS could increase the cell viability to a certain extent. However, following the addition of PDTC, the cell viability was suppressed. When APS was used at $100 \mu \mathrm{g} / \mathrm{ml}$ with PDTC, PDTC exerted no suppressive effects on cell viability.

APS promotes cytokine secretion from RAW264.7 cells. RAW264.7 cell treatment with APS resulted in a marked increase in the concentrations of IL-1 $\beta$, TNF- $\alpha$ and NO in a dose-dependent manner (Fig. 3A, C and G). The gene expression levels were evaluated by RT-qPCR. The results demonstrated that following APS stimulation, the mRNA expression levels of pro-inflammatory factors and chemokines were increased (Fig. 3B, D, F and H). Following treatment with APS at $50 \mu \mathrm{g} / \mathrm{ml}$, IL-6 expression was significantly increased (Fig. 3C) compared the $0 \mu \mathrm{g} / \mathrm{ml}$ APS treatment group $(\mathrm{P}<0.01)$. At $100 \mu \mathrm{g} / \mathrm{ml}$ APS treatment, the production of IL-1 $\beta$, IL-6 and NO were significantly increased (Fig. 3A, C and G) compared with the $0 \mu \mathrm{g} / \mathrm{ml}$ APS treatment group $(\mathrm{P}<0.01)$, whereas PDTC was able to inhibit the increase of IL-1 $\beta$, IL-6 and NO (Fig. 3A, C, E and G; $\mathrm{P}>0.05)$. Compared with the $0 \mu \mathrm{g} / \mathrm{ml}$ APS treatment group, the production of TNF- $\alpha$ have an increased trend with the increased concentration of APS, but there was no significance (Fig. 3E; P>0.05). Compared with $100 \mu \mathrm{g} / \mathrm{ml}$ APS, the levels of IL-6 and NO in the APS $100 \mu \mathrm{g} / \mathrm{ml}+$ PDTC treatment group were significantly decreased (Fig. 3C and G; $\mathrm{P}<0.01$ ). Compared with the $0 \mu \mathrm{g} / \mathrm{ml}$ APS treatment group, IL- 6 mRNA expression was significantly increased (Fig. 3D; $\mathrm{P}<0.01)$ in the APS $25 \mu \mathrm{g} / \mathrm{ml}$ treatment group $(\mathrm{P}<0.01)$ and the IL-1 $\beta$ and IL-6 mRNA expression levels were significantly higher (Fig. 3B and $\mathrm{D} ; \mathrm{P}<0.01)$ in the APS $50 \mu \mathrm{g} / \mathrm{ml}$ group $(\mathrm{P}<0.01)$. The expression of IL-1 $\beta$, IL- 6 , TNF- $\alpha$ and iNOS mRNA in the APS $100 \mu \mathrm{g} / \mathrm{ml}$ group were significantly increased (Fig. 3B, D, F and H; P<0.01) compared with $0 \mu \mathrm{g} / \mathrm{ml} \mathrm{APS}$ treatment group $(\mathrm{P}<0.01)$. These results demonstrated that PDTC inhibited the effects of APS.

APS upregulates the expression of surface molecules on RAW264.7 cells. The expression of CD40, CD80 and CD86 on RAW264.7 cells treated with APS were measured by flow cytometry (Fig. 4). Compared with the $0 \mu \mathrm{g} / \mathrm{ml}$ APS treatment group, the expression levels of CD40 increased gradually with increasing concentrations of APS. Following treatment with $100 \mu \mathrm{g} / \mathrm{ml}$ APS, CD40 expression reached 55.20\%; however, following the addition of PDTC, the expression levels of CD40 decreased. Compared with $100 \mu \mathrm{g} / \mathrm{ml}$ APS, CD40 expression levels decreased in the $100 \mu \mathrm{g} / \mathrm{ml}$ APS + PDTC group. APS exerted no effects on CD80 expression. CD86 secretion increased from 36.47 to $66.72 \%$ with $25-100 \mu \mathrm{g} / \mathrm{ml}$ APS, while PDTC inhibited APS-induced upregulation on CD86 expression.

APS promotes cell proliferation by inducing cell cycle progression in RAW264.7 cells. As shown in Fig. 5 and Table II, APS increased the ratio of $\mathrm{G} 2 / \mathrm{M}$ cells in a dose-dependent manner, where the effects of $100 \mu \mathrm{g} / \mathrm{ml}$ APS was the most prominent. The addition of PDTC lowered the ratio of $\mathrm{G} 2 / \mathrm{M}$ cells. The number of $\mathrm{G} 2 / \mathrm{M}$ phase cells was slightly higher compared with the $0 \mu \mathrm{g} / \mathrm{ml}$ APS treatment group when both APS and PDTC were administered simultaneously. Therefore, the results indicated that APS promoted cell proliferation.

APS promotes p65 expression in RAW264.7 cells. EMSA was performed using nuclear protein extracts to assess p65 expression in the nucleus (Fig. 6). APS treatment resulted in an increase of p65 expression in a dose-dependent manner. However, this effect was inhibited by PDTC. Compared with the $0 \mu \mathrm{g} / \mathrm{ml}$ APS treatment group, the expression levels of p65 in the nucleus significantly increased in the $25 \mu \mathrm{g} / \mathrm{ml}$ $(\mathrm{P}<0.05), 50 \mu \mathrm{g} / \mathrm{ml}(\mathrm{P}<0.01)$ and $100 \mu \mathrm{g} / \mathrm{ml}$ APS $(\mathrm{P}<0.01)$ groups. Compared with $100 \mu \mathrm{g} / \mathrm{ml}$ APS, p65 expression of p65 significantly decreased in the $100 \mu \mathrm{g} / \mathrm{ml}$ APS + PDTC group $(\mathrm{P}<0.01)$. These results suggested that PDTC can inhibit the expression of p65 in the nucleus, opposing the effects of APS treatment. 
A
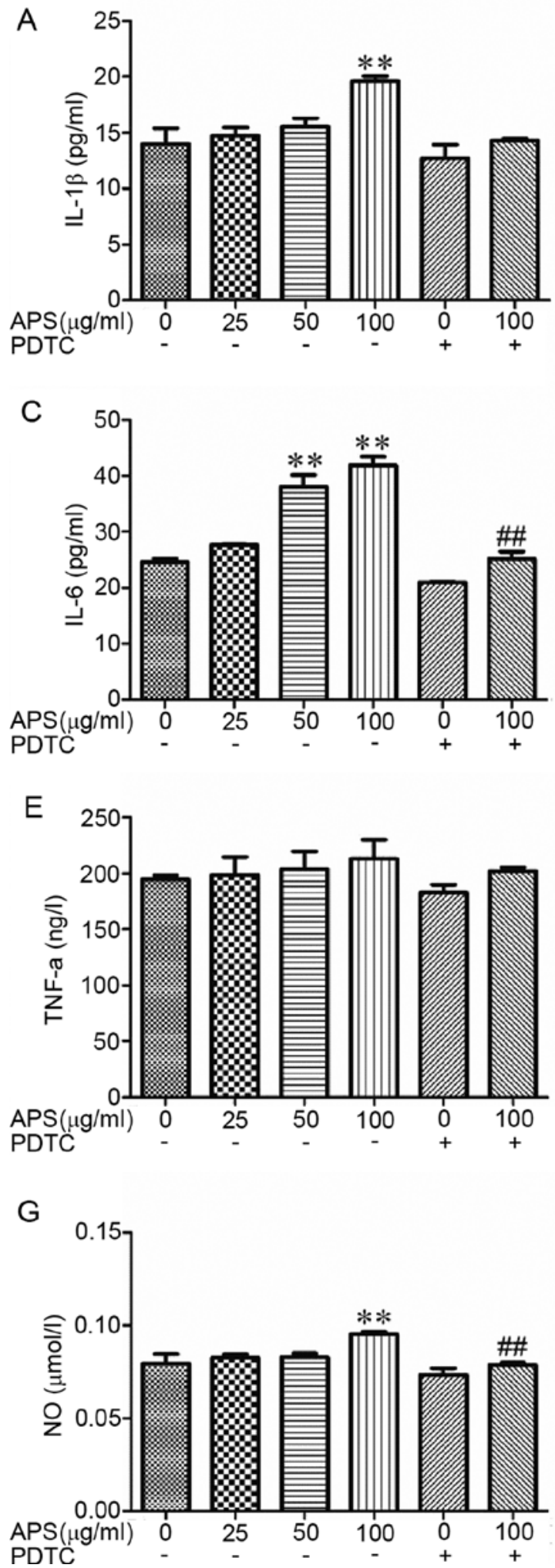
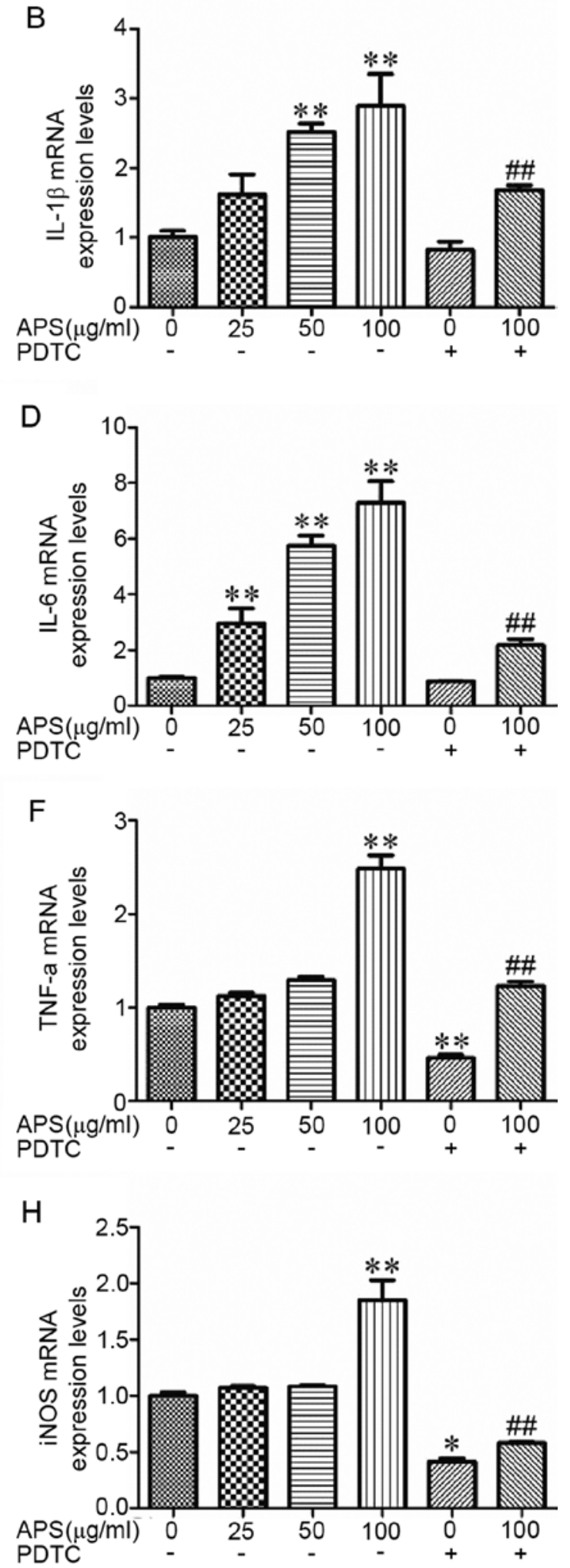

Figure 3. Effects of APS on cytokine and NO content and mRNA expression. NO contents were detected by ELISA. The mRNA expression levels of cytokines and iNOS were detected by reverse transcription-quantitative PCR. Cells were treated with $0,25,50$ and $100 \mu \mathrm{g} / \mathrm{ml}$ APS in the absence or presence of $10 \mu \mathrm{mol} / \mathrm{ml}$ PDTC. The (A) content and (B) mRNA levels of IL-1 $\beta$; (C) content and (D) mRNA levels of IL-6; (E) content and (F) mRNA levels of TNF- $\alpha$; and $(\mathrm{G})$ content of NO and $(\mathrm{H}) \mathrm{mRNA}$ levels of iNOS. ${ }^{*} \mathrm{P}<0.05$ and ${ }^{* *} \mathrm{P}<0.01 \mathrm{vs} .0 \mu \mathrm{g} / \mathrm{ml}$ APS treatment group. ${ }^{\# \#} \mathrm{P}<0.01 \mathrm{vs}$. $100 \mu \mathrm{g} / \mathrm{ml}$ APS treatment group. All values are expressed as the mean \pm standard deviation of at least five replications in each treatment. APS, Astralagus polysaccharide; PDTC, pyrrolidine dithiocarbamate; NO, nitric oxide; iNOS, inducible nitric oxide synthase.

APS activates the NF- $\kappa B / M A P K$ signaling pathway in $R A W 264.7$ cells. Western blot analysis results are shown in Fig. 7. The levels of p-p65 in RAW264.7 cells increased significantly with increasing concentrations of APS. Compared with the $0 \mu \mathrm{g} / \mathrm{ml}$ APS treatment group, the levels of NF- $\kappa B$ p65, p-p38, p-JNK and p-ERK were significantly increased 


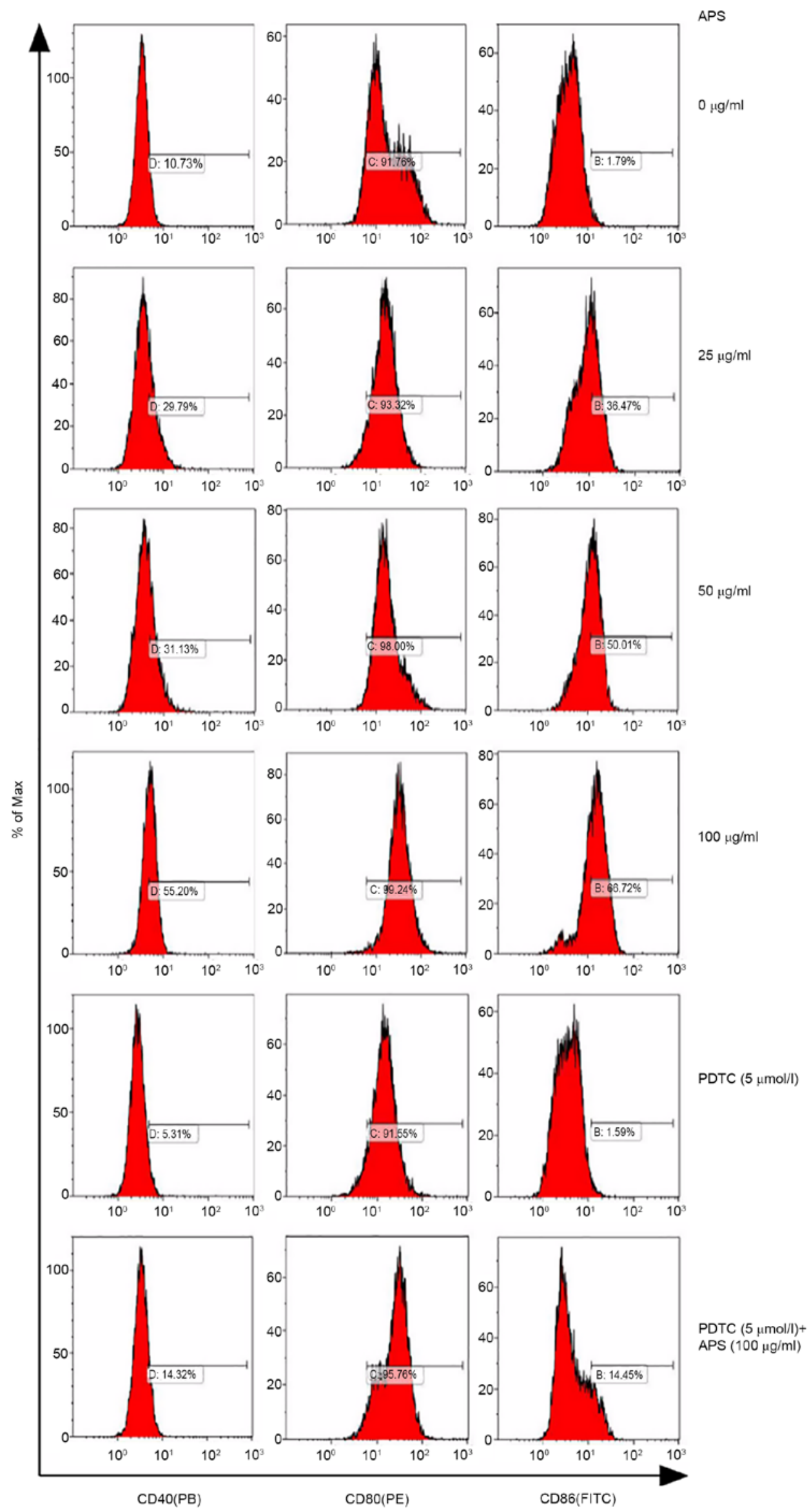

Figure 4. Effects of APS on CD40, CD80 and CD86 secretion. Key membrane molecules were measured by flow cytometry. Cells were treated with different concentrations $(0-100 \mu \mathrm{g} / \mathrm{ml})$ of APS in the absence or presence of $5 \mu \mathrm{mol} / \mathrm{ml} \mathrm{PDTC}$. From left to right, expression of CD40 (PB), CD80 (PE) and CD86 (FITC). After the cell surface factors was detected by flow cytometry, the results were expressed in the histogram. APS, Astralagus polysaccharide; PDTC, pyrrolidine dithiocarbamate; PE, phycoerythrin. 
Table II. Cell cycle data.

\begin{tabular}{|c|c|c|c|c|c|c|}
\hline \multirow[b]{2}{*}{ Items } & \multicolumn{4}{|c|}{$\operatorname{APS}(\mu \mathrm{g} / \mathrm{ml})$} & \multirow{2}{*}{$\begin{array}{c}\text { PDTC } \\
(5 \mu \mathrm{mol} / 1)\end{array}$} & \multirow{2}{*}{$\begin{array}{c}\text { PDTC } \\
(5 \mu \mathrm{mol} / \mathrm{l})+100 \mu \mathrm{g} / \mathrm{ml} \mathrm{APS}\end{array}$} \\
\hline & 0 & 25 & 50 & 100 & & \\
\hline RMS & 1.66 & 2.57 & 2.17 & 2.32 & 2.16 & 1.46 \\
\hline Freq.G1 & 86.20 & 66.44 & 80.31 & 66.57 & 75.84 & 96.54 \\
\hline Freq.S & 5.48 & 14.02 & 12.37 & 15.70 & 14.70 & 3.41 \\
\hline Freq.G2 & 2.45 & 7.01 & 8.40 & 15.65 & 2.26 & 2.68 \\
\hline G1 mean & 201.93 & 194.46 & 190.73 & 192.66 & 208.15 & 210.00 \\
\hline G2 mean & 383.19 & 379.63 & 373.81 & 368.87 & 387.07 & 376.00 \\
\hline G1 cv & 6.42 & 6.65 & 8.54 & 6.76 & 7.96 & 7.19 \\
\hline $\mathrm{G} 2 \mathrm{cv}$ & 6.24 & 2.98 & 3.35 & 5.90 & 1.74 & 11.44 \\
\hline Freq.sub-G1 & 5.62 & 14.38 & 4.46 & 3.34 & 9.25 & 2.91 \\
\hline Freq.sub-G2 & -0.75 & -0.46 & -0.13 & -1.19 & -0.05 & -0.82 \\
\hline
\end{tabular}

APS, Astragalus polysaccharide; PDTC, pyrrolidine dithiocarbamate; RMS, root mean square; Freq, frequency; cv, coefficient of variation .
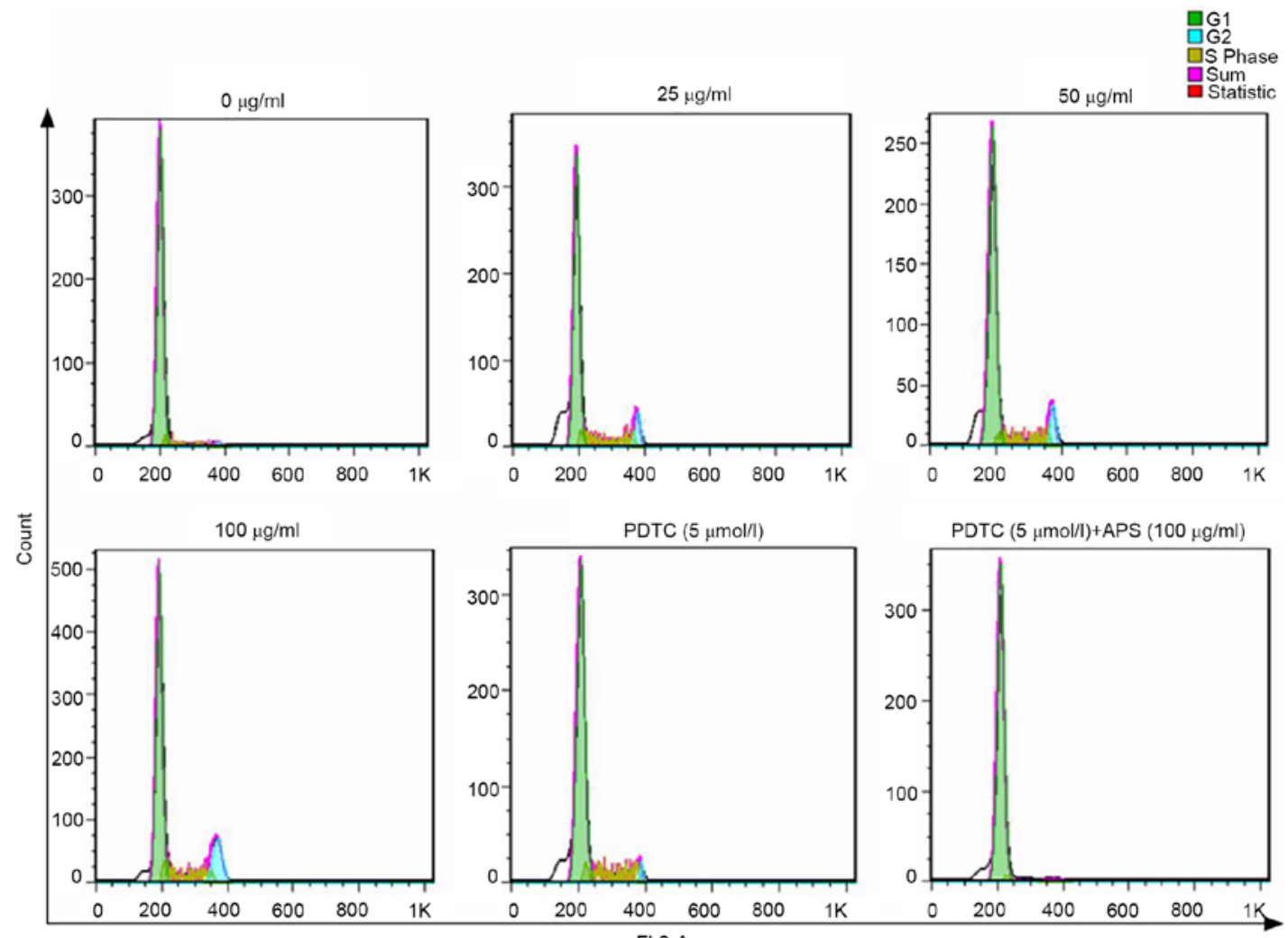

Figure 5. Effects of APS on the cell cycle. The cell cycle was measured by flow cytometry. Cells were treated with different concentrations $(0-100 \mu \mathrm{g} / \mathrm{ml})$ of APS in the absence or presence of $5 \mu \mathrm{mol} / \mathrm{ml}$ PDTC. APS, Astralagus polysaccharide; PDTC, pyrrolidine dithiocarbamate.

in the $25-100 \mu \mathrm{g} / \mathrm{ml}$ APS groups. Compared with $100 \mu \mathrm{g} / \mathrm{ml}$ APS, the levels of p-p38 and p-JNK were decreased in the $100 \mu \mathrm{g} / \mathrm{ml}$ APS + PDTC group.

\section{Discussion}

APS is the main bioactive ingredient of Astragalus membranaceus and is widely studied for their immunopotentiating components on murine B-cell proliferation stimulation $(22,23)$. Besides, previous studies reported that APS can promote cell proliferation within a certain concentration range (24). To investigate the immune regulation of APS, CCK-8 assay was taken. In the present study, the result showed that different concentrations of APS increased the proliferation of cells to a certain extent which indicated that APS promoted the differentiation of RAW264.7. In addition, it is reported that APS was 

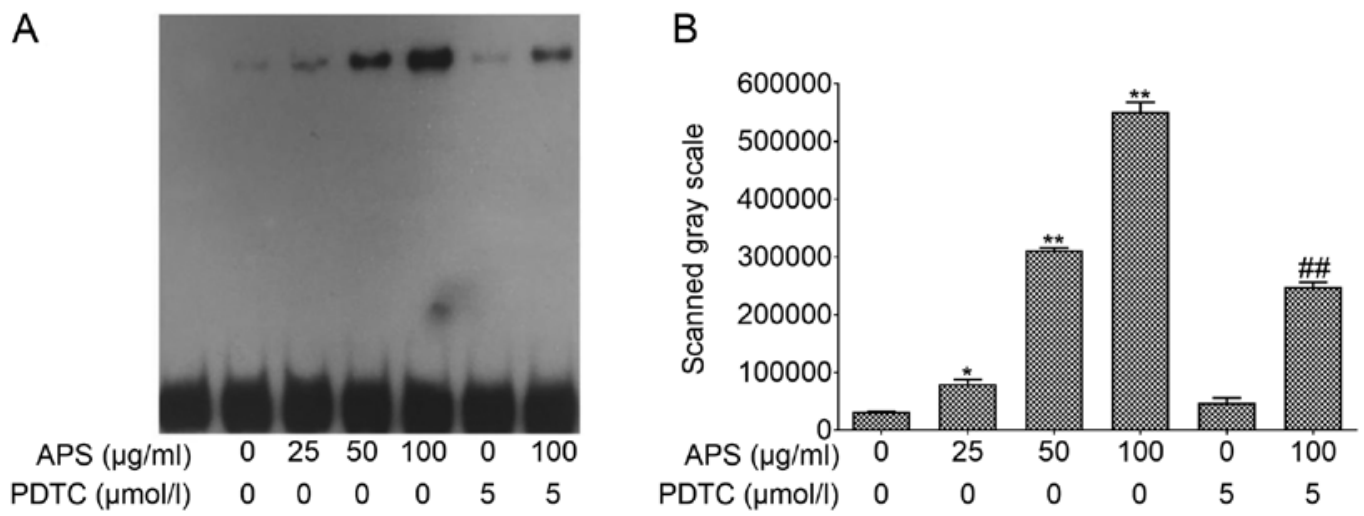

Figure 6. Effects of APS on the expression of transcription factor p65 in the nucleus. (A) The electrophoretic mobility shift assay (EMSA) result of NF- $\mathrm{B}$ p65. (B) The EMSA scanned gray scale of NF- $\kappa B$ p65. ${ }^{*} \mathrm{P}<0.05$ and ${ }^{* *} \mathrm{P}<0.01 \mathrm{vs} 0 \mu \mathrm{g} / \mathrm{ml}$ APS treatment group. ${ }^{\# \#} \mathrm{P}<0.01 \mathrm{vs}$. $100 \mu \mathrm{g} / \mathrm{ml}$ APS treatment group. All values are expressed as the mean \pm standard deviation of at least three replications in each treatment. APS, Astralagus polysaccharide; PDTC, pyrrolidine dithiocarbamate.

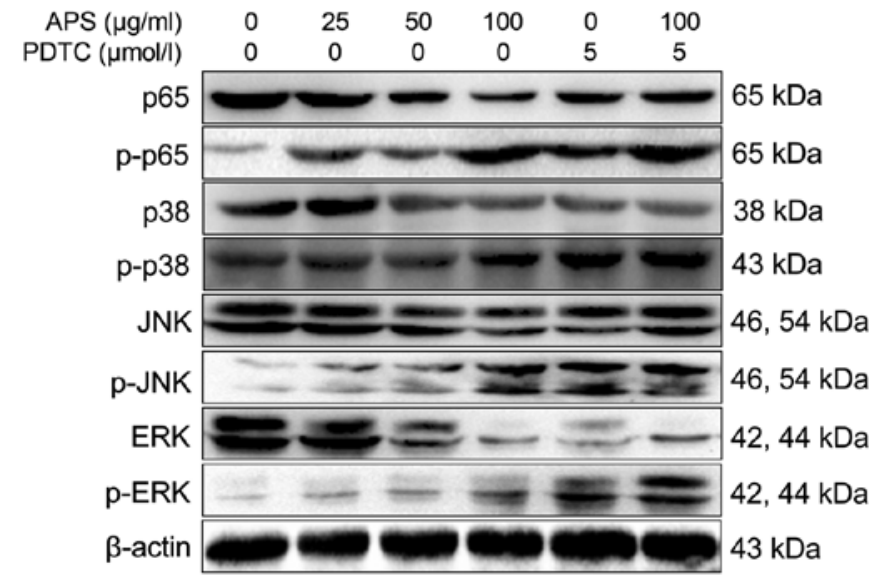

Figure 7. Effects of APS on the expression of key molecules involved in the MAPK signaling pathway. All values are expressed as the mean \pm standard deviation of at least three replications in each treatment. APS, Astralagus polysaccharide; PDTC, pyrrolidine dithiocarbamate; p, phosphorylated.

not associated with toxic effects in 3T3-L1 adipocytes and ob/ob diabetic mice (25). Our results further confirm that APS play a vital role in RAW264.7 differentiation without cytotoxicity. Meanwhile, APS was shown to potentiate immune response of murine macrophages via increasing the production of IL-1 $\beta$ and TNF- $\alpha$ (23). It was previously reported that pachymaran polysaccharides enhance cellular immune function by increasing the secretion of NO and TNF- $\alpha$ in macrophages (26). Pleurotus nebrodensis polysaccharide can activate RAW264.7 cells and increase the expression of IL-6, TNF- $\alpha$, IFN- $\gamma$, NO and iNOS, thereby exerting an immune-enhancing effect (7). In a study of mice, APS significantly suppressed coxsackievirus B3-induced expression of IL-1 $\beta$, IL- 6 , TNF- $\alpha$, INF- $\gamma$ and MCP-1 in the heart (27). In addition, APS can modulate cytokine-induced immune dysfunction, mainly by downregulation of the expression of IL-1 $\beta$, IL-2, IL- 6 , TNF- $\alpha$ and IFN- $\gamma$ in non-obese diabetic mice T-cell subsets (28). However, it is not clear whether APS can induce the production of cytokines in RAW264.7 in vitro. The results of the present study demonstrated that APS promoted the secretion of IL-1 $\beta$, IL- 6 and TNF- $\alpha$ and increased the content of NO in RAW264.7 cells, which indicated that APS can enhance the immune function of RAW264.7 cells by directly promoting the production of cytokines. It is well known that the production of cytokines is regulated on transcriptional, post-transcriptional and translational level (29). Furthermore, it was demonstrated that polysaccharides can exert immunopotentiation effects by increasing the levels of cytokines and NO and enhancing gene expression (30). In the present study, the levels of IL-1 $\beta$, IL-6, TNF- $\alpha$ and NO were measured. The results demonstrated that the expression of IL- $1 \beta$, IL- 6 , TNF- $\alpha$ and iNOS was increased after treated with APS and was decreased after inhibitor PDTC treatment. These results suggest that APS can promote the expression of cytokines and the production of NO, exerting potent immunomodulatory effects.

CD40, CD80 and CD86 are antigen-presenting cells that play a costimulatory role in immune response regulation (31). Previous studies indicate that CD40, CD80 and CD86 are indispensable for immune responses and inducing the expression of cytokines (32). In the present study, APS increased the secretion of CD40 and CD80 in RAW264.7 cells. There is no significant changes in the secretion of CD80. On the basis of these findings, CD40 and CD80, not CD 86, are included in the immune regulation stimulated with APS. It is reported that G1 period and S period are preparing for the presynthesis of RNA and synthesis of DNA, respectively (31). The regulation of the cell cycle is necessary to cell proliferation (33). It was found that APS exhibited an anti-proliferative effect on cancer and displayed differentiation induction on erythroid (34). In the present study, the G2/M of RAW264.7 cells was gradually increased with the increased APS and was lowed with the inhibitor PDTC treatment. Combined with the viability results, APS promoted the proliferation of RAW264.7 cells.

APS regulates immune function through a variety of extracellular and intracellular signaling pathways, of which the most important is the NF- $\kappa \mathrm{B}$ signaling pathway (35-39). $\mathrm{NF}-\kappa \mathrm{B}$ plays a key role in the regulation of immune and inflammatory responses through phosphorylation, DNA binding, dimerization and nuclear translocation methods $(39,40)$. p65 is key in the activation of the NF- $\kappa \mathrm{B}$ family of transcription factors and translocates from the cytoplasm to the nucleus after stimulation $(41,42)$. In the present study, p65 nuclear 
translocation increased in RAW264.7 cells treated with APS as determined by EMSA. The results demonstrated that different concentrations of APS could promote p65 nuclear translocation, particularly at high concentration, whereas PDTC could inhibit the function of APS. It is reported that p38, JNK and ERK MAPK signaling pathway is upstream of IL-1 $\beta$, IL-6 and TNF- $\alpha(43,44)$. As one of the main components of Radix Astragali, Astragaloside IV was found to increase the phosphorylation of p65, p38, ERK and JNK (31). Limited studies report whether APS affects the protein expression of $\mathrm{p} 65$ and MAPK. To further investigate the roles of APS in the MAPK and NF- $\kappa$ B pathways, western blotting was used. In the present study, western blotting results revealed that the levels of p-p65, p-p38, p-JNK and p-ERK were significantly increased following treatment with APS. The changes of p65 and MAPK were reversed by the inhibitor PDTC. These results suggested that APS can enhance immune function via the NF- $\kappa \mathrm{B}$ p65/MAPK signaling pathway and PDTC can suppress the effects of APS. Overall, the activation of NF- $\mathrm{BB}$ p65/MAPK signaling pathway provides a molecular explanation for the well-known immune regulation with APS.

In conclusion, the results of the present study demonstrated that APS affected the expression of inflammatory cytokines and associated genes, promoting the secretion of co-stimulatory molecules on the surface of RAW264.7 cells and promoted cell proliferation to enhance immune function partly via the $\mathrm{NF}-\kappa \mathrm{B} / \mathrm{MAPK}$ signaling pathway. However, the present study did not perform in vivo studies, which will further clarify the immunoregulatory effects of APS. However, the present study provided a foundation for further investigation of the immune function enhancement of APS.

\section{Acknowledgements}

Not applicable.

\section{Funding}

This research was funded by the National Key Research and Development Program of China (grant no. 2016YFD0501009) and the Project of Modern Agricultural Industry and Technology System of Anhui Province (grant no. AHCYJSTX-07).

\section{Availability of data and materials}

The datasets used and/or analyzed during the present study are available from the corresponding author on reasonable request.

\section{Authors' contributions}

SF and YL performed the experiments, collected the results and wrote the manuscript. HD, LL, CP, YH, FZ, WL and TM contributed to data analysis and manuscript revision. JL, XW, YL and JW conceived the study and contributed to reviewing/editing the manuscript. All authors read, approved the final manuscript and agreed to be accountable for all aspects of the research in ensuring that the accuracy or integrity of any part of the work are appropriately investigated and resolved.

\section{Ethics approval and consent to participate}

Not applicable.

\section{Patient consent for publication}

Not applicable.

\section{Competing interests}

The authors declare that they have no competing interests.

\section{References}

1. Liu J, Zhao ZZ and Chen HB: Review of Astragali radix. Chin Herb Med 2: 90-105, 2011.

2. Zhao LH, Ma ZX, Zhu J, Yu XH and Weng DP: Characterization of polysaccharide from Astragalus radix as the macrophage stimulator. Cell Immunol 271: 329-334, 2011.

3. Wang X, Li Y, Yang X and Yao J: Astragalus polysaccharide reduces inflammatory response by decreasing permeability of LPS-infected Caco2 cells. Int J Biol Macromol 61: 347-352, 2013.

4. Kong X, Hu Y, Rui R, Wang D and Li X: Effects of Chinese herbal medicinal ingredients on peripheral lymphocyte proliferation and serum antibody titer after vaccination in chicken. Int Immunopharmacol 4: 975-982, 2004.

5. Xu HD, You CG, Zhang RL, Gao P and Wang ZR: Effects of Astragalus polysaccharides and astragalosides on the phagocytosis of Mycobacterium tuberculosis by macrophages. J Int Med Res 35: 84-90, 2007.

6. Han J, Yue WP, Guang-Zhi HE and Tian WY: Effects of polysaccharide of eight traditional chinese medicine on cy tokine releasing from mouse macrophages. Curr Immunol 31: 495-498, 2011.

7. Sun H, Zhang J, Chen F, Chen X, Zhou Z and Wang H: Activation of RAW264.7 macrophages by the polysaccharide from the roots of Actinidia eriantha and its molecular mechanisms. Carbohydr Polym 121: 388-402, 2015.

8. Choi YH, Jin GY, Li GZ and Yan GH: Cornuside suppresses lipopolysaccharide-induced inflammatory mediators by inhibiting nuclear factor-kappa B activation in RAW 264.7 macrophages. Biol Pharm Bull 34: 959-966, 2011.

9. Dunzendorfer S, Lee HK, Soldau K and Tobias PS: TLR4 is the signaling but not the lipopolysaccharide uptake receptor. J Immunol 173: 1166-1170, 2004

10. Hsu BY, Kuo YC and Chen BH: Polysaccharide Isolated from Zizyphus jujuba ( Hóng Zăo) Inhibits Interleukin-2 Production in Jurkat T Cells. J Tradit Complement Med 4: 132-135, 2014.

11. Van Gool SW, Vandenberghe P, de Boer M and Ceuppens JL: CD80, CD86 and CD40 provide accessory signals in a multiple-step T-cell activation model. Immunol Rev 153: 47-83, 1996.

12. Chang TT, Kuchroo VK and Sharpe AH: Role of the B7-CD28/CTLA-4 pathway in autoimmune disease. Curr Dir Autoimmun 5: 113-130, 2002.

13. Yellin MJ, Brett J, Baum D, Matsushima A, Szabolcs M, Stern D and Chess L: Functional interactions of T cells with endothelial cells: The role of CD40L-CD40-mediated signals. J Exp Med 182: 1857-1864, 1995.

14. Harlan DM, Hengartner H, Huang ML, Kang YH, Abe R, Moreadith RW, Pircher H, Gray GS, Ohashi PS and Freeman GJ: Mice expressing both B7-1 and viral glycoprotein on pancreatic beta cells along with glycoprotein-specific transgenic $\mathrm{T}$ cells develop diabetes due to a breakdown of T-lymphocyte unresponsiveness. Proc Natl Acad Sci USA 91: 3137-3141, 1994.

15. Khatua $S$ and Acharya K: Alkali treated antioxidative crude polysaccharide from Russula alatoreticula potentiates murine macrophages by tunning TLR/NF-кB pathway. Sci Rep 9: 1713, 2019.

16. Jia XJ, Li X, Wang F, Liu HQ, Zhang DJ and Chen Y: Berbamine Exerts Anti-inflammatory effects via inhibition of NF- $\kappa \mathrm{B}$ and MAPK signaling pathways. Cell Physiol Biochem 41: 2307-2318, 2017.

17. Zhou L, Liu Z, Wang Z, Yu S, Long T, Zhou X and Bao Y: Astragalus polysaccharides exerts immunomodulatory effects via TLR4-mediated MyD88-dependent signaling pathway in vitro and in vivo. Sci Rep 7: 44822, 2017. 
18. Du X, Chen X, Zhao B, Lv Y, Zhang H, Liu H, Chen Z, Chen Y and Zeng X: Astragalus polysaccharides enhance the humoral and cellular immune responses of hepatitis B surface antigen vaccination through inhibiting the expression of transforming growth factor $\beta$ and the frequency of regulatory T cells. FEMS Immunol Med Microbiol 63: 228-235, 2011.

19. Zhang S: Effects of water soluble alfalfa and Astragalus polysaccharide on proliferation of lymphocyte in broilers. Chin J Anim Nutr 22: 670-674, 2010

20. Li Y, Hao N, Zou SP, Meng TT, Tao HQ, Ming PF, Li MM, Ding HY, Li JC, Feng SB, et al: Immune regulation of RAW264. 7 cells in vitro by flavonoids from Astragalus complanatus via activating the NF- $\kappa$ B signalling pathway. J Immunol Res 2018: 1-9, 2018.

21. Livak KJ and Schmittgen TD: Analysis of relative gene expression data using real-time quantitative PCR and the 2(-Delta Delta C(T)) Method. Methods 25: 402-408, 2001.

22. Li XT, Zhang YK, Kuang HX, Jin FX, Liu DW, Gao MB, Liu Z and Xin XJ: Mitochondrial protection and anti-aging activity of Astragalus polysaccharides and their potential mechanism. Int J Mol Sci 13: 1747-1761, 2012.

23. Shao BM, Xu W, Dai H, Tu P, Li Z and Gao XM: A study on the immune receptors for polysaccharides from the roots of Astragalus membranaceus, a Chinese medicinal herb. Biochem Biophys Res Commun 320: 1103-1111, 2004.

24. Zhang NW, Li JF, Hu YX, Cheng GL, Zhu XY, Liu FQ, Zhang YJ, Liu ZJ and Xu JQ: Effects of Astragalus polysaccharide on the immune response to foot-and-mouth disease vaccine in mice. Carbohydr Polym 82: 680-686, 2010.

25. Ma L, Huang L, Pei H, Liu Z, Xie C, Lei L, Chen X, Ye H, Peng A and Chen L: Pharmacological effects of the water fraction of key components in the traditional Chinese prescription Mai Tong Fang on 3T3-L1 adipocytes and ob/ob diabetic mice. Molecules 19: 14687-14698, 2014.

26. Chung HS, Shin CH, Lee EJ, Hong SH and Kim HM: Production of nitric oxide and tumor necrosis factor-alpha by Smilacis rhizoma in mouse peritoneal macrophages. Comp Biochem Physiol C Toxicol Pharmacol 135: 197-203, 2003.

27. Liu T, Zhang M, Niu H, Liu J, Ruilian M, Wang Y, Xiao Y, Xiao Z, Sun J, Dong Y, et al: Astragalus polysaccharide from Astragalus Melittin ameliorates inflammation via suppressing the activation of TLR-4/NF- $\mathrm{KB}$ p65 signal pathway and protects mice from CVB3-induced virus myocarditis. Int J Biol Macromol 126 179-186, 2019.

28. Wei C, Li YM, Yu MH and Shi XM: Immunoloregulation effects of Astragalus polysaccharides on T helper lymphocyte subgroups in nonobese diabetic mice. China J Mod Med 17: 28-35, 2007 (In Chinese)

29. Stoecklin G, Mayo T and Anderson P: ARE-mRNA degradation requires the 5'-3' decay pathway. EMBO Rep 7: 72-77, 2006.

30. Luo T, Qin J, Liu M, Luo J, Ding F, Wang M and Zheng L: Astragalus polysaccharide attenuates lipopolysaccharide-induced inflammatory responses in microglial cells: Regulation of protein kinase $\mathrm{B}$ and nuclear factor- $\mathrm{\kappa} \mathrm{B}$ signaling. Inflamm Res 64: 205-212, 2015.

31. Li Y, Meng T, Hao N, Tao H, Zou S, Li M, Ming P, Ding H, Dong J, Feng $\mathrm{S}$, et al: Immune regulation mechanism of Astragaloside IV on RAW264.7 cells through activating the NF- $\mathrm{KB} / \mathrm{MAPK}$ signaling pathway. Int Immunopharmacol 49: 38-49, 2017.
32. Li J, Wang F, Wang G, Sun Y, Cai J, Liu X, Zhang J, Lu X, $\mathrm{Li} \mathrm{Y}$, Chen $\mathrm{M}$, et al: Combination epidermal growth factor receptor variant III peptide-pulsed dendritic cell vaccine with miR-326 results in enhanced killing on EGFRvIII-positive cells. Oncotarget 8: 26256-26268, 2017.

33. Wang Z, Deng X, Xiong R, Xiong S, Liu J, Cao X, Lei X, Chen Y, Zheng $X$ and Tang G: Design, synthesis and biological evaluation of $3^{\prime}, 4^{\prime}, 5^{\prime}$-trimethoxy flavonoid benzimidazole derivatives as potential anti-tumor agents. MedChemComm 9: 305-315, 2017.

34. Zong A, Cao $\mathrm{H}$ and Wang F: Anticancer polysaccharides from natural resources: A review of recent research. Carbohydr Polym 90: 1395-1410, 2012.

35. Jiang CL, Tang C, Qiang Y, Suo HY and Li L: Immunoregulation effect of Astragalus polysaccharides. Shipin Kexue 94: 90-99, 2013.

36. Wang Z, Liu Z, Zhou L, Long $\mathrm{T}$, Zhou $\mathrm{X}$ and Bao Y: Immunomodulatory effect of APS and PSP is mediated by $\mathrm{Ca}^{2+}-\mathrm{cAMP}$ and TLR4/NF- $\kappa \mathrm{B}$ signaling pathway in macrophage. Int J Biol Macromol 94: 283-289, 2017.

37. Chen JL, Zhang YQ, Yuan Y, Wu SR and Ming J: Progress in research on immune-regulatory effects of plant polysaccharides on macrophages through NF- $\mathrm{KB}$ signaling pathway. Food Sc 36: 288-294, 2015

38. Chen JL, Zhang YQ, Yuan Y, Wu SR and Ming J: Research progress on the immune-regulatory effects for macrophages of plant polysaccharides by NF- $\kappa$ B signaling pathway. Klin Oczna 46: 1441, 2015

39. Lamparter CL, Philbrook NA and Winn LM: Valproic acid increases NF- $\mathrm{B}$ B transcriptional activation despite decreasing DNA binding ability in P19 cells, which may play a role in VPA-initiated teratogenesis. Reprod Toxicol 74: 32-39, 2017.

40. Panday A, Inda ME, Bagam P, Sahoo MK, Osorio D and Batra S: Transcription factor NF- $\kappa \mathrm{B}$ : An update on intervention strategies. Arch Immunol Ther Ex 64: 1-21, 2016.

41. Zhang Q, Lenardo MJ and Baltimore D: 30 years of NF- $\mathrm{B}$ : A blossoming of relevance to human pathobiology. Cell 168: 37-57, 2017.

42. Zhang JZ, Liu N, Sun C, Sun DQ and Wang YJ: Polysaccharides from polygonatum sibiricum delar. ex redoute induce an immune

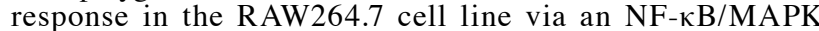
pathway. RSC Advances 9: 17988-17994, 2019.

43. Cho JW, Lee KS and Kim CW: Curcumin attenuates the expression of IL-1 $\beta$, IL- 6 , and TNF- $\alpha$ as well as cyclin E in TNF- $\alpha$-treated HaCaT cells; NF-kappaB and MAPKs as potential upstream targets. Int J Mol Med 19: 469-474, 2007.

44. Fisher WG, Yang PC, Medikonduri RK and Jafri MS: NFAT and NFkappaB activation in T lymphocytes: A model of differential activation of gene expression. Ann Biomed Eng 34: 1712-1728, 2006.

This work is licensed under a Creative Commons Attribution-NonCommercial-NoDerivatives 4.0 International (CC BY-NC-ND 4.0) License. 